\title{
HEDGING THROUGH THE USE OF MODAL AUXILIARIES IN ENGLISH ACADEMIC DISCOURSE
}

\author{
Tofan Dwi Hardjanto ${ }^{1}$ \\ ${ }^{1}$ English Study Program, Faculty of Cultural Sciences, Universitas Gadjah Mada, Yogyakarta \\ Email: deha@ugm.ac.id
}

\begin{abstract}
As a communicative strategy, hedging plays a central role in academic writing. Numerous different linguistic forms can be used to express this strategy. This article attempts to investigate modal auxiliary verbs as the principal means of expressing hedging in English academic discourse. For this purpose, a corpus of 75 primary empirical research articles from economics, linguistics, medicine, natural sciences and engineering was analyzed quantitatively with the help of corpus linguistic method. The results revealed that modal auxiliaries were used most frequently in linguistics and economics and least frequently in engineering and natural sciences while their use in medicine came in between. This seems to suggest that there is noticeable disciplinary variation in the degree of hedging through the use of modal auxiliaries in English research articles. Modal auxiliaries tend to be more common in soft sciences than in hard sciences whereas their use in health sciences in comparison with soft and hard sciences does not seem to show any significant difference.
\end{abstract}

Keywords: academic discourse, hedging, modal auxiliaries, modality, research articles

\section{INTRODUCTION}

Hedges, as originally defined by Lakoff (1973: 471), are "words whose meaning involves fuzzinesswords whose job is to make things fuzzier or less fuzzy". This concept has been used and subsequently extended to such an extent that hedges are now commonly viewed, especially in academic discourse, as realizations of a communicative startegy called 'hedging' (e.g., Hyland, 1996b, 1998; Markkanen \& Schr $\square$ der, 1989, 1992, 1997; Myers, 1989; SalagerMeyer, 1994, 1997, 2011; Skelton, 1988ab). As a communicative strategy, hedging seems to have been understood differently by different scholars. It is sometimes considered as the expression of tentativeness and possibility (e.g., Crismore \& Vande Kopple, 1988; Hyland, 1996b; Salager-Meyer, 2011). For Markkanen \& Schr $\square$ der $(1989,1992)$, hedging serves to modify the writer's responsibility to the truth of the propositions expressed, or modify the weightiness of the information given or modify the writer's attitude to the information. However, for Myers (1989: 12), "[h] edging is a politeness strategy when it marks a claim, or any other statement, as being provisional, pending acceptance in the literature, acceptance by the community-in other words, acceptance by the readers".

In academic writing, hedging plays a crucial role (Crismore dan Farnsworth, 1990; Hyland, 1996b, 1998; Myers, 1989; Salager-Meyer, 1994; Swales, 1990). Whereas Crismore dan Farnsworth (1990: 135) view hedging as "the mark of a professional scientist, one who acknowledges the caution with which he or she does science and write on science", Hyland (1996b: 433) considers it as "central in academic writing where the need to present unproven proposisitons with caution and precision is essential". In addition to indicating professionalism, caution and precision, hedging also expresses "honesty, modesty and proper caution in 
self-reports and for diplomatically creating space in areas heavily populated by other researchers" (Swales, 1990: 175). Probably most importantly hedging serves as a marker of knowledge claims. Myers (op. cit.: 13) argues that "a sentence that looks like a claim but has no hedging is probably not a statement of new knowledge". Likewise, Hyland (1998) suggests that hedging can be used as a strategy for presenting new knowledge.

As an important communicative strategy, hedging can be realized by a large variety of linguistic forms. In fact, it can be argued that an indefinite number of surface forms can be used to express hedging (Brown \& Levinson, 1987; Markkanen \& Schr $\square$ der, 1997). Various attempts have been made to categorize these forms (e.g., Crompton, 1997; Hyland, 1996a, 1998; SalagerMeyer, 1994, 1997; Skelton, 1988b). Common to all of these categorizations of hedging forms is a category of modal auxiliary verbs (modal auxiliaries for short). This seems to imply, therefore, that modal auxiliaries serve a very important role in hedging in English academic discourse. Moreover, modal auxiliaries also belong to the concept of modality which cuts across the concept of hedging (Markkanen \& Schr $\square$ der, 1997; Mauranen, 1997). Discussions of modality, in English particularly, have concentrated mostly on modal auxiliaries (e.g., Coates, 1983; 1995; Collins, 2009; Depraetere \& Reed, 2006; Palmer, 2001). It is therefore the aim of this article to investigate hedging through the use of modal auxiliaries in English academic writing. In particular, it attempts to examine the frequency and distribution of modal auxiliaries used to express hedging in research articles published in various international journals from a number of different disciplines. In other words, it seeks to specifically answer the following questions: (a) How frequently are modal auxiliaries used in English research articles across five disciplines? (b) Is there variation in the frequency and distribution of the modal auxiliaries used as hedges in English research articles across the five disciplines?

\section{MODALITY AND MODAL AUXILIARIES IN ENGLISH}

Modality has attracted so much attention that as Perkins (1983: 4) argues, "doing research on modality is very similar to trying to move in an overcrowded room without treading on anyone else's feet". It has indeed been studied from the points of view of language philosophy (Fine, 2005), semantics (mis., Boland, 2006; Coates, 1983; Leech, 2004; Lyons, 1977; Palmer, 2001; Perkins, 1983), and pragmatics (Klinge, 1993; Stubbs, 1986; Turnbull \& Saxton, 1997). In general, modality, according to Lyons (1977: 452), is concerned with a speaker's "opinion or attitude towards the proposition that the sentence expresses or the situation that the proposition describes", whereas according to Huddleston \& Pullum (2002: 173), it is concerned with "the speaker's attitude towards the factuality or actualization of the situation expressed by the rest of the clause". An utterance containing a modal expression does not represent the situation as a fact. Depraetere \& Reed suggest that "all modal utterances are non-factual, in that they do not assert that the situations they describe are facts, and all involve the speaker's comment on the necessity or possibility of the truth of the proposition or the actualization of a situation."

As the perspectives from which modality is viewed vary, its categorizations also vary. For example, Bybee \& Fleishman (1985) distinguish between agent-oriented modality and epistemic modality; Coates (1983) between root modality and epistemic modality; Halliday (2014) between modulation and modalization; Huddleston \& Pullum (2002) between deontic modality, epistemic modality and dynamic modality; Palmer (2001) between propositional modality and event modality; Quirk et. al. (1985) between intrinsic modality and extrinsic modality; and Van der Auwera \& Plungian (1998) between epistemic modality and non-epistemic modality. Table 1 shows these classifications of modality as summarized by Depraetere \& Reed (2006: 280).

However, attention has mostly been paid to epistemic modality and deontic or root modality. While deontic modality is the modality of obligation and is concerned with the speaker's necessity and obligations or readiness towards the action or inclination, epistemic modality is concerned with "the speaker's assumptions, or assessment of possibilities, and in most cases, it indicates the speaker's confidence or lack of confidence in the truth of the proposition expressed" (Coates, 1987: 112). For Perkins (1983: 10), epistemic modality 
indicates the speaker's lack of knowledge about the truth of the proposition. For Lyons (1977: 797), however, an utterance containing epistemic modality is an utterance "in which the speaker explicitly qualifies his commitment to the truth of the proposition expressed by the sentence he utters, whether this qualification is made explicit in the verbal component (...) or in the prosodic or paralinguistic component." As hedging expresses tentativeness, possibility and uncertainty, it is much closer to epistemic modality than deontic modality.

Table 1

Classifications of modality (adapted from Depraetere \& Reed (2006: 280))

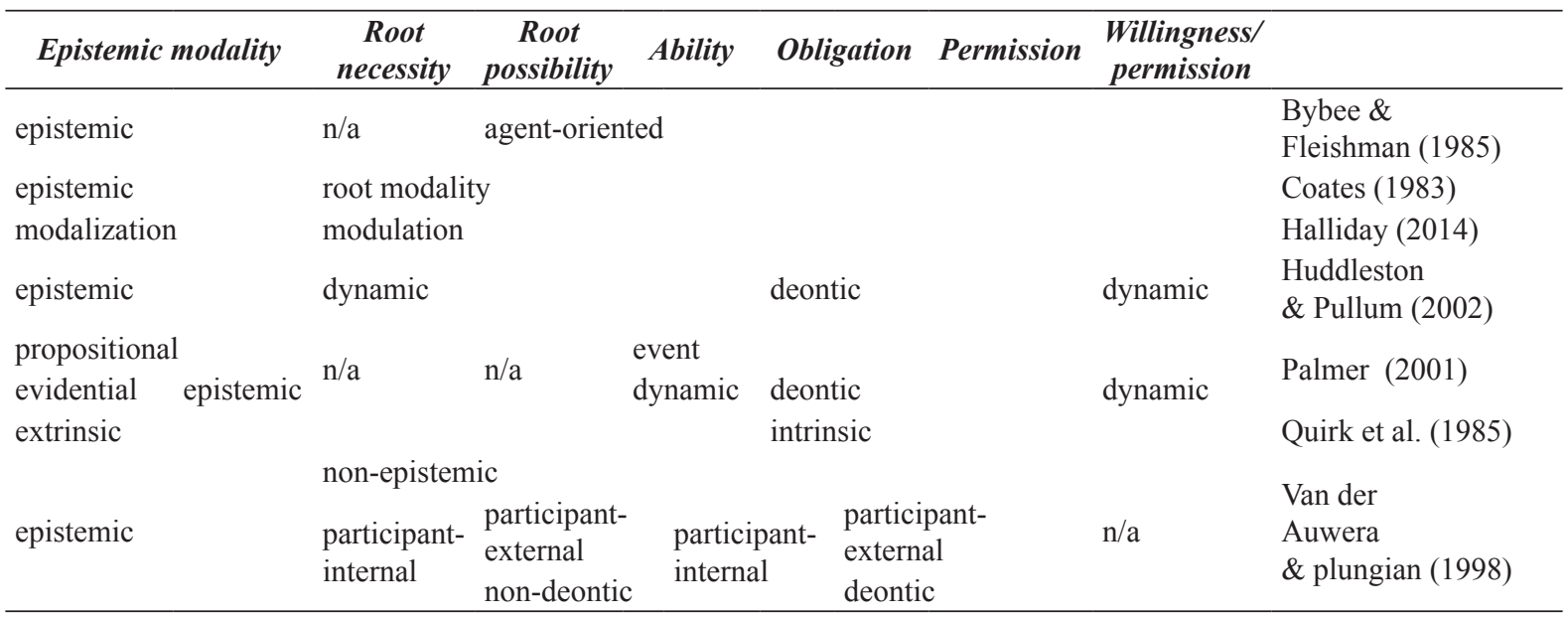

In English particularly, modality is commonly expressed through the use of modal auxiliaries. These auxiliaries are generally used to express "degree of certainty" and "degree of obligation" (Carter \& McCarthy, 2006: 898). Coates (1983) has discussed in detail the range of meanings that such modal auxiliaries can convey, as summarized in Table 2 below.

Table 2

Summary of the meanings of modal auxiliaries (Coates, 1983)

\begin{tabular}{|c|c|}
\hline $\begin{array}{c}\text { Modals } \\
\text { Auxiliaries }\end{array}$ & Meanings \\
\hline can & ability, root possibility, permission \\
\hline could & $\begin{array}{l}\text { root possibility, epistemic possibility, ability, } \\
\text { hypothesis }\end{array}$ \\
\hline may & $\begin{array}{l}\text { root possibility, epistemic possibility, } \\
\text { permission }\end{array}$ \\
\hline might & $\begin{array}{l}\text { root possibility, epistemic possibility, } \\
\text { permission, hypothesis }\end{array}$ \\
\hline must & strong obligation, confident inference \\
\hline shall & $\begin{array}{l}\text { strong obligation, volition, prediction, } \\
\text { determination }\end{array}$ \\
\hline should & $\begin{array}{l}\text { weak obligation, tentative inference, } \\
\text { hypothesis, necessity }\end{array}$ \\
\hline will & volition, prediction, predictability \\
\hline
\end{tabular}

Modal auxiliaries belong to the larger class of auxiliaries, including primary auxiliary verbs be, do and have (Quirk et. al., 1972: 69). Like all auxiliary verbs, the modal auxiliaries syntactically differ from lexical verbs in their capacity to be used in what Huddleston \& Pullum (2002: 93) call NICE constructions (Negation, Inversion, Code and Emphasis). In addition, the modal auxiliaries have other properties which are distinctive to them: (a) they only have tensed forms; (b) they do not show any agreement with the subject; (c) they take bare infinitival complements; (d) they are used as the first verb in an unreal conditional construction; and (e) there is much less restriction in the use of their preterites with the modal remoteness meaning than with other verbs. (For further information, see Huddleston \& Pullum (2002: 106-107)). These properties differentiate between what Quirk et.al. (1985: 137) call central modals (can, could, may, might, shall, should, will, would, must) and marginal modals (dare, need, ought to, used to). Modal auxiliriaries, especially central modals, constitute the principal means of expressing epistemic modality. Therefore, this study focuses on the central modal auxiliaries used as realizations of hedging in English academic discourse. 


\section{MATERIALS AND METHODS}

This study is corpus-based in that corpus data are used not only for illustrative purposes only but also as a source of quantitative information. This computer-assisted study with a sizeable corpus hinges on the principle that "the more material the analysis is based on, the safer the conclusions drawn will be, and the more generalisable the results will be" (Ädel, 2006: 8). Moreover, as Hyland (1998: 94) argues, "an analysis of a representative corpus can identify the most common features of the linguistic system we use, frequency being seen as one measure of significance."

To achieve the goal of the study as mentioned above, a corpus was generated, consisting of 75 primary, empirical research articles (RAs), 15 articles each from the fields of economics (106,800 words), linguistics (120,509 words), medicine (57,814 words), natural sciences ( 75,078 words) and engineering (83,541 words), thus amounting to a total of 443,742 running words, excluding the abstracts, formulas, equations, table titles, references and endnotes or footnotes. The five fields of study represent soft sciences (economics and linguistics), hard sciences (natural sciences and engineering) and health sciences (medicine). This was done so as to detect whether there is variation in the use of modal auxiliaries to express hedging in the three clusters of sciences. The 75 articles were published in various international journals in the period between 2009-2011. All the selected journals were listed in Thompson Reuter's 2009 Arts and Humanities Citation Index, Science Citation Index Expanded or Social Science Citation Index.

As mentioned previously, various types of linguistic forms can be used to express hedging. This study focuses only on one type, i.e., the central modal auxiliaries can, could, may, might, shall, should, will, would and must. Data containing these modal auxiliaries were retrieved using WordSmith Tools 5 (Scott, 2008). However, it should be borne in mind that as these modals can be used to express hedging as well as other meanings, all the collected data had to go through a process called 'sifting', i.e., "choosing search terms that will yield a large number of hits, and then manually discarding the irrelevant ones" (Ädel, 2006: 47). Thus, in this study, only sentences containing modal auxiliaries used to express tentativeness, possibility, doubt and uncertainty were included as the data for analysis. To investigate variation in the use of modal auxiliriaries in the research articles, the data were analyzed in terms of the frequency and distribution of the modals in the five disciplines. For ease of reference and for illustrative purposes, all sentences containing modal auxiliaries used as hedging devices were coded with the letters E, L, M, N, G as a shorthand respectively for economics, linguistics, medicine, natural sciences and engineering, followed by a number and the letters I, M, R, D for Introduction, Methods, Results and Discussion, representing rhetorical sections of the research article. Thus, a sentence given the code E01D, for example, indicates that it was taken from the Discussion section of the first article in economics.

As the lengths of the articles in each of the five disciplines vary, the counting of modal auxiliaries used in the articles in each discipline was conducted, not on the basis of raw occurrences, but on the basis of normalized occurrences of the modals used to express hedging. Normalization here refers to "a way to convert raw counts into rates of occurrence, so that the scores from texts of different lengths can be compared" (Biber \& Jones, 2009: 1299). In this study, all the modal auxiliaries used as hedging in the corpus were normalized as per 10,000 words using the following formula:

Normalized frequency $=\frac{\text { Frequency }(\text { Raw count }) * 10,000}{\text { Number of words }}$

For instance, if 100 instances of may were used as hedges in the 15 research articles in economics, which contains 106,800 words, then its normalized or relative frequency is 100 times 10,000 divided by 106,800 which is equal to 9.7 . Following Pho (2013), the constant 10,000, not 1,000 as used, for example, by Hyland (1998) and Varttala (2001), was selected to avoid expected frequencies of less than 5 , which would make the chi-square test unreliable. McEnery \& Wilson (2001: 83-84) suggest that whichever option is selected is not crucial as long as it is indicated which option is used. 


\section{RESULTS AND DISCUSSION}

Almost all of the nine central modal auxiliaries were found to be used to express hedging in the corpus. However, no instance of shall was found as a hedging device. Table 3 shows the overall frequency and distribution of the eight modal auxiliaries used to express hedging in the corpus.

As can be seen in the table, the modal auxiliaries are most frequently used in linguistics (38.9 per 10,000 words) and economics (38.6) and least frequently in engineering (21.7) and natural sciences (21.0), while their use in medicine (29.9) comes in between. Statistical analysis using Minitab Release 17 software by means of the chisquare test with a significant level, or $p$-value, set at 0.05 , which is common for social studies, including linguistics (Gomez, 2004: 244; Sanjaya, 2013: 95), reveals that the distribution of the modal auxiliaries differ somewhat significantly in the five disciplines under investigation $\left(\chi_{(4)}^{2}=10.1589\right.$, $p=0.038)$. This seems to suggest that modal auxiliaries tend to be more frequently used in soft sciences than in hard sciences, whereas the use of these modals in health sciences in comparison with soft and hard sciences does not seem to show any significant difference. This finding also seems to be consistent with that of Varttala (2001) where modal auxiliaries are used most frequently in economics (51.8) and least frequently in engineering (19.5) whereas in medicine the use of this modal is in between (34.2).

Table 3

Frequency and distribution of modal auxiliaries across five disciplines (per 10,000 words)

\begin{tabular}{lcccccc}
\hline $\begin{array}{c}\text { Modal } \\
\text { auxiliaries }\end{array}$ & $\begin{array}{c}\text { Econo- } \\
\text { mics }\end{array}$ & $\begin{array}{c}\text { Linguis- } \\
\text { tics }\end{array}$ & $\begin{array}{c}\text { Medi- } \\
\text { cine }\end{array}$ & $\begin{array}{c}\text { Natural } \\
\text { Sciences }\end{array}$ & $\begin{array}{c}\text { Engineer- } \\
\text { ing }\end{array}$ & Mean \\
\hline may & 16.0 & 15.8 & 9.3 & 7.7 & 10.9 & 11.9 \\
would & 5.9 & 8.5 & 5.5 & 4.7 & 4.1 & 5.7 \\
will & 10.8 & 5.9 & 2.1 & 2.8 & 2.4 & 4.8 \\
might & 2.1 & 2.6 & 6.4 & 1.5 & 0.5 & 2.6 \\
could & 1.5 & 1.7 & 4.7 & 2.8 & 1.8 & 2.5 \\
should & 1.9 & 3.4 & 1.6 & 0.3 & 1.3 & 1.7 \\
can & 0.3 & 1.0 & 0.3 & 1.1 & 0.5 & 0.6 \\
must & 0.2 & 0.1 & - & 0.3 & 0.2 & 0.2 \\
\hline \multicolumn{1}{c}{ Total } & $\mathbf{3 8 . 6}$ & $\mathbf{3 8 . 9}$ & $\mathbf{2 9 . 9}$ & $\mathbf{2 1 . 0}$ & $\mathbf{2 1 . 7}$ & $\mathbf{3 0 . 0}$ \\
\hline
\end{tabular}

The table also shows some individual differences in the use of modal auxiliaries as hedges. As can be seen, the most frequently used modal auxiliary was may and the least was must across the five disciplines. It is interesting to note that the second most frequently used modal differed across the disciplines. While would was the second most frequently used modal in linguistics, natural sciences and engineering, it was the third most frequently used modal after will in economics and after might in medicine. It is also interesting to note that some noticeable differences were observed between the results of the present study and those from previous studies, particularly those of Hyland (1998) and Varttala (2001). One obvious difference was the use of would where in Hyland's corpus it was ranked first as the most frequently used modal while in the present corpus it was ranked second and in Varttala it was ranked fifth. However, while in both this study and Varttala's may was found to be the most common hedge, it was ranked second in Hyland's. It can also be observed that will was very frequently used as hedges in this corpus but it was not both in Hyland's and Varttala's corpora. Furthermore, could was more commonly used in both Hyland's and Varttala's than in this corpus. The same is true for might. Interestingly, the use of should was found to be similar in the three corpora. In short, the distributions of modal auxiliaries in the three corpora differ significantly $\left(\chi_{(12)}^{2}=\right.$ $180.793, p<0.001)$. In other words, the three corpora show significantly different patterns of use of modal auxiliaries as hedging devices.

What reasons underlie these disciplinary differences in the use of modal auxiliaries as hedges? A number of scholars have made some suggestions regarding such differences (see, e.g., Bondi, 2006; Hyland, 1999, 2008; Malavasi \& Mazzi, 2008; Taylor \& Chen, 1991). Taylor \& Chen (1991), for example, suggest that disciplinary cultures play an important role in shaping disciplinary discourses. But according to Hyland (1999), rhetorical constraints within a discipline affect disciplinary differences, whereas Bondi (2006) speculates that the main reason behind such differences lies in the language used (see also Malavasi \& Mazzi, 2008). Similarly, Hyland (2008) also believes that discipline specificity lies in language. Furthermore, he argues that different disciplines value different kinds of arguments and also vary in what their readers already know and how they might be persuaded. Consequently, 
Hyland believes that philosophers do not write like linguists or physicists. He suggests that disciplines make up a continuum with hard sciences like natural sciences and enginerring at one end and soft sciences such as economics and linguistics at the other. While hard sciences are regarded as objective, empirical, quantitative, utilizing experimental methods, putting greater emphasis on methods, procedures and equipment, showing linear and cumulative growth, and not relying on rhetoric, soft sciences are treated as interpretive and qualitative, using discursive argument and more fluid discourses, and putting greater weight on the strength of argument to present knowledge claims. Hyland (2008) claims that hard sciences tend to use more modals such as could and may in order to objectify their research.

As shown above, the results seem to support Hyland's (2008) contention above that authors from different discipline write differently. It was found that in terms of the use of modal auxiliries as hedging devices, authors from economics, for example, do not seem to write like those from engineering or from medicine. The five disciplines do seem to range along a cline with engineering and natural sciences at one end and linguistics and economics at the other whereas medicine lies in between. However, it is important to note that while engineering and natural sciences, and to a large extend also medicine, tended to put more emphasis on methods, procedures and equipment, and rely less on rhetoric, linguistics and economics were also found to be objective, empirical and quantitative, putting a lot of weight on methods and procedures. Moreover, the results of the present research do not seem to support Hyland's (2008) claim that authors from hard sciences use more modals such as may and would to objectify their research. On the contrary, the results show that soft sciences like linguistics and economics make more use of modal auxiliaries, suggesting that they seem to be more tentative and cautious in presenting new knowledge claims.

In what follows, I will look more closely into how the modal auxiliaries were used as hedges in the data, beginning with the most commonly used modals.

\section{May/Might}

The modal auxiliaries may and also its preterite form might have often been considered as the prototypical hedging devices (Hyland, 1998: 116). This is evident from the relatively high frequency of use of these modals found in this study and in Hyland (1998) and Varttala (2001) as well as in those reported in Hyland (op. cit.: 107). May can be used to express epistemic and non-epistemic modality. Its epistemic meaning can be readily differentiated from their non-epistemic meaning through paraphrase, i.e., as it is possible that or it may be that for its epistemic meaning and as it is possible for for its non-epistemic meaning. While epistemic may can co-occur with the adverbs possibly and well, which "imply probability where the auxiliary alone connoted only possibility" (Quirk et. al., 1985: 588), non-epistemic may cannot. Epistemic may can also co-occur with the perfect aspect, but this is rare with non-epistemic may (Butler, 1990: 147).

In most cases (78.6\%) may in this study was found to be used to express epistemic meaning, and as Table 3 above shows, it was found to be the most commonly used modal auxiliary across the five disciplines. The predominant use of may is to be expected as previous studies have shown that may is most typically used as a token of epistemic meaning (Coates, 1983; Collins, 2009). Collins (ibid:: 92) found in the three corpora he examined, i.e., the British component of the International Corpus of English ('ICE-GB'), the Australian component of the International Corpus of English ('ICE-AUS'), and a specially assembled corpus of American English ('C-US'), that $79 \%$ of may was used with epistemic meaning and only $15.1 \%$ with non-epistemic meaning, while the remaining with inderteminate meaning which Coates (1983: 145) calls a "merger" between epistemic and deontic modality. Below are some examples of may used as a hedging device in the data. In these examples, may indicates the RA writers' lack of confidence in the truth of the propositions expressed in each of the sentences. In cases like these, as Huddleston \& Pullum (2002: 182) argue, "[epistemic] may triggers a strong implicature that I don't know that the proposition is true. If I knew that it was 
true, I would normally be expected to use the unmodalised form-He's ill, say, rather than the much weaker He may be ill'".

(1) The importance of association rights for the German data may reflect cultural differences in the quality and quantity of friendship relations. (L01D)

(2) It $\underline{\operatorname{mav}}$ well be the case that there are differences in other coefficients, for instance different returns to experience and education, both acquired in the country of origin and the destination country. ${ }^{11}$ (E13R)

(3) The observed anomalous behaviors of the formulations during residual curing $\underline{\text { may }}$ be possibly due to the additional reactions between the propagating cation and these functional groups. (G15R)

Similarly, might was more commonly used with epistemic meaning $(63.6 \%)$ than with nonepistemic meaning (36.4\%). This is slightly lower than that reported in Collins (2009: 109) where epistemic may accounted for $77.2 \%$ of tokens, and much lower than that in Brewer (1987) where it amounted to $81.4 \%$. The two examples below illustrate the use of might as a hedging device. Might here expresses epistemic possibility and tentativeness.

(4) Future work $\underline{\text { might } \boldsymbol{t}}$ fruitfully examine exactly how neighborhood demographics and preservation policy affect one another. (E10D)

(5) The same reasoning might explain the structural basis for promiscuous proteins, which recognize multiple partners with essentially the same set of interfacial residues. (N14D)

It should be noted, however, that in presentday English, as Coates (1983: 157) argues, might is very rarely used as a past-time equivalent of may (cf. Perkins, 1983: 54; Huddleston \& Pullum, 2002: 203). It has been suggested (e.g., Hermerén, 1978; Palmer, 1990; Perkins, 1983) that in terms of likelihood, might indicates a lower degree than may. In addition, might also expresses a higher degree of tentativeness: the truth of the proposition expressed in the sentence where might is used is more tentative than may. However, Coates (1983) reports that may and might were found to express similar degrees of likelihood in her data. Coates (ibid. : 152) contends that "MIGHT, in my data at least, does not seem to express a more tentative meaning than MAY" (original emphasis). Collins (2009: 111) supports this claim, reporting that in his data numerous cases of epistemic may and might were used alternately without any apparent difference in tentativeness.

As far as both modal auxiliaries are used as hedging devices, these differing viewpoints are in fact not really significant (Varttala, 2001). However, they can be very important in terms of the effects that both may have on the reader. This is true particularly in scientific communication where a scientist's success and reputation often depend on considerations of degrees of confidence in the information that $\mathrm{s} /$ he presents. Therefore, as Varttala (ibid.: 107) argues, "although may and might are perhaps at times used interchangeably, their potential meaning distinction should merit at least some thought for example in pedagogical materials relating to scientific communication."

\section{WILL/WOULD}

Like may and might, will and its past tense form would can also be used to express epistemic and non-epistemic modality. Will is more commonly used to express epistemic meaning than non-epitemic meaning. Brewer (1987: 220), for instance, reports that will was mostly (95\%) used to express epistemic meaning in political discourse in the U.K. Besides, Collins (2009: 126) also found that this modal auxiliary was mostly used with epistemic meaning (59.2\%), 30.4\% with dynamic meaning, $1.7 \%$ with deontic meaning and the remaining $5.2 \%$ with inderteminate meaning. In this study will was mostly found as a hedging device expressing epistemic meaning (64.9\%). As a hedging device, however, on average, will was found to be slightly lower than would. The examples below illustrate the use of will as a hedging device with epistemic meaning.

(6) As many of the variables used in this analysis would presumably also be significant in a hedonic price equation, 
they will likely not serve as valid instruments for policy choice.(E10D)

(7) If the focus is on the risk estimate and its associated confidence interval, a patient who starts treatment will be eligible to drive after being seizure-free for six months. (M07D)

(8) The computed seismic modulus will vary by frequency according to the master curve in undamaged, homogeneous asphalt concrete. (G08M)

As an expression of epistemic modality, will can be used to indicate prediction (Coates, 1983: 169 ) or futurity (Huddleston \& Pullum, 2002: $188)$ as shown in (6) above. Coates (op. cit.: 184) argues that in academic writing the use of will indicating prediction implies a lower degree of the writers' commitment to the factuality of what they say. Moreover, she observes that in science an utterance expressing prediction is not the same in terms of tentativeness as an utterance presenting results deduced from clear evidence. In addition, as prediction is closely related to futurity, Huddleston \& Pullum (2002: 190) suggest that "our knowledge about the future is inevitably much more limited than our knowledge about the past and the present, and what we say about the future will typically be perceived as having the character of a prediction rather than an unqualified factual assertion." Therefore, such use of will was treated as a hedge in this study. This is probably partly the reason why will was used much more frequently in this study than in those of Hyland (1998) and Varttala (2001).

In addition to prediction, will also indicates predictability (Coates, 1983: 169) as illustrated in (7) above. This is what Huddleston \& Pullum (2002: 188) call "'central-epistemic" use of will. This will can convey a higher degree of the RA writers' confidence in the truth of the proposition based on evidence and knowledge of a present or past situation and it is very common in science, especially as expressed in the form of conditionals (Leech, 2004: §126). Semantically, predictability will is comparable in strength to epistemic must. As Huddleston \& Pullum (op. cit.: 189) argue, “ $[\mathrm{m}]$ ust conveys the idea of conclusion, and is often used in explanations (...). With central-epistemic will it is more a matter of assumption or expectation, very often with suggestion of future confirmation (...)."

Turning now to would, like will, it is more commonly used as an expression of epistemic modality than deontic or dynamic modality. In this study, would was more frequently used to express epistemic modality $(69.1 \%)$ than non-epistemic modality $(30.9 \%)$. This is consistent with Collins' (2009: 140) findings in which the modal auxiliary was more frequently used with epistemic meaning (64.3\%) than with dynamic meaning (22.9\%) (see also Brewer, 1987: 233). Below are some examples illustrating the use of would as a hedge.

(9) Our main hypothesis was that differences would emerge in the kind of offenses reported by the five different groups, and indeed they did. (L01D)

(10) Most importantly, if the silane layer was damaged or oxidized during the long deposition time, the highly polar $\mathrm{C} 1 \mathrm{~s}$ peaks, indicating $\mathrm{CO}$ or $\mathrm{CN}$, would be quite large. (N01R

(11) We argue that investigating the interaction between OI narrative and legitimacy when organizations respond to environmental changes would provide a significant contribution. (E05R)

(12) It would seem that physicians were responding judiciously in integrating the published evidence into their practices. (M02D)

Coates (1983), Leech (2004) and Perkins (1983) all suggest that would, like could, might and should, is commonly used as a grammatical expression of hypotheticality as exemplified in (9). According to Coates (1983: 205ff), would is used as the main hypothetical modal auxiliary with epistemic meaning and in scientific writing it is commonly used as the hypothetical alternative of will expressing prediction and predictability. As an expression of hypotheticality, would is often found in the apodosis, or main clause, of an unreal conditional (10). However, as example (11) shows, sometimes the protasis, or subordinate clause, is not explicitly expressed. This is what Leech (2004: §185) calls 'pure hypothesis'. Leech (ibid.) argues that this use of hypothetical would is a common feature of written English, especially academic 
writing. It can be used by the writers as an evasive or defensive strategy and to distance their claim from reality. If used together with such verbs as appear, seem, suggest and tend, as illustrated in (12), such hypothetical would indicates a higher degree of tentativeness.

\section{Can/Could}

Unlike the previous modal auxiliaries, can is most commonly used to express dynamic modality. Collins (2009: 98) reports that $81 \%$ of can was used with dynamic meaning, 9.9\% with deontic meaning, $1.1 \%$ with epistemic meaning and the rest with inderteminate meaning. Brewer (1987: 257,291 ) did not find even a single use of can with epistemic meaning. In his data, this modal was mostly used to convey dynamic meaning (95.5\%) and the remaining $4.5 \%$ deontic meaning. Likewise, in this study, it was mostly used with non-epistemic meaning (97.5\%) and only $2.5 \%$ with epistemic meaning.

It should be noted that as an expression of epistemic modality, can has attracted differing opinions. For some scholars (e.g., Butler, 1990; Coates, 1983; Leech, 2004), can is not directly linked to epistemic modality. Coates (1983), for instance, treats can only as a suppletive form for must, providing the missing non-affirmative form in the epistemic must paradigm. For other scholars (e.g., Butler, 1990; Collins, 2009; Huddleston \& Pullum, 2002; Hyland, 1998), can may serve as a marker of epistemic possibility only in interrogative or negative constructions. In this study, as a hedging device, can was mostly used in negative constructions and only a small proportion in interrogatives. Used in a negative construction, can indicates the non-existence of epistemic possibility (it is not possible that), while in an interrogative construction, it is used to question epistemic possibility. The examples below illustrate the use of can as a hedge in both negative and interrogative contexts.

(13) Thus, it cannot be the case that any analysis will reveal entirely distinct repertoires, particularly when the resource are shared (...). (L07D)

(14) How $\underline{\text { can }}$ the N-peptide regulate fusion with such spatial flexibility?
Like can, could can be used to convey deontic, dynamic or epistemic meaning. In this study, it was used more commonly as an expression of non-epistemic than epistemic modality with a ratio of $85.5 \%$ to $14.5 \%$. This ratio is similar to that reported by Collins (2009: 109), i.e., $85.9 \%$ to $14.1 \%$ and Brewer (1987: 219), i.e., $94.2 \%$ to $5.8 \%$. This modal was also rarely used as a marker of epistemic meaning in Butler's (1990) and Coates' (1983) data.

While can indicates epistemic possibility only in negative and interrogative environments, could, like may and might, can be used to express tentative possiblity in an affirmative context as illustrated in (15) below. Occasionally it is used in harmonic combinations (Halliday, 1970: 331; Lyons, 1977: 807) with other modal auxiliaries, especially may, might and would. As exemplified in (16) below, the use of could in such combinations implies that the RA writers attempt to be cautious with their tentative claims. Furthermore, could can also be used together with modal lexical verbs (e.g., appear, believe, indicate, speculate, suggest), modal adjectives (e.g., likely, possible), modal adverbs (e.g., perhaps, well), and modal nouns (e.g., conclusion, possibility, suggestion). Examples 17-20 below illustrate the use of could in such combinations.

(15) It is possible that the effect of the press could be different in less predictable contexts, such as a merger announcement or a change in management. (E07D)

(16) Embarassment about seeking services could also be related to traditional barriers such as stigma, but it might also be associated with cultural barriers such as fear of loss of face..$^{41,43,70}$ (M05D)

(17) This could suggest that interactions are only transient and may be restricted to appressoria (i.e., a stage not yet accessible to biochemical analysis). (N10D)

(18) It is unlikely that this has biased analyses, however, as patients with a recurrence within six months of their first seizure could not contribute to the risk estimates presented in this paper (...). (M07D)

(19) Weighed against this, however, some 
respondents may recall the previous community-based health insurance study and believe that the re-organization could well occur (...). (E06D)

(20) This is consistent with Polka's suggestion $(1991,1992)$ that a high degree of phonetic similarity between two non-native segments could increase perceptual difficulty for the listener. (L12D)

\section{Should and Must}

Should is commonly used to convey nonepistemic (i.e., deontic) meaning and only occasionally epistemic meaning. In this study, it was mostly used with non-epistemic meaning $(81.3 \%)$ and only $18.7 \%$ with epistemic meaning. This is not much different from Brewer's (1987) and Collins' (2009) findings. Brewer (1987: 244) reports that should was much more commonly used with deontic meaning (84\%) and the remaining $16 \%$ with epistemic meaning. Likewise, Collins (ibid.: 45) found that non-epistemic should was more frequently used $(88.2 \%)$ than epistemic should $(11.8 \%)$.

As an expression of epistemic modality, should indicates a somewhat extreme possibility, or a reasonable assumption or conclusion; it is therefore possible that the speaker is mistaken (Palmer, 1990: 59). Consequently, such use of should can be treated as a hedging device because it expresses "a tentative assumption, assessment of probability, based on facts known to the speaker" (Coates, 1983: 64). Example (21) below illustrates this use of should. The tentativity of should can also be detected from its use together with such modal auxiliaries as may, could and would (22) or with such modal lexical verbs as argue, assume, predict, suggest and tend (23). Besides, as exemplified in (24), should can also be used in conditional constructions in which it "expresses slightly greater doubt than the non-modal counterpart" (Huddleston \& Pullum, 2002: 188).

(21) Given these findings, culturally relevant services and outreach to these communities should be mindful of generational differences. (M05D)

(22) As a result, the solutions may not be truly optimal, but should provide a reasonable estimate of the actual variation in layer thickness and modulus. (G08M)

(23) Assuming that their commitment to the project also serves as a catalyst of its commercial success and artistic recognition, its scale should be proportional to the potential that they detect in it early on. (E11I)

(24) If they derive from distinct configurations of the resources available for the construction of dialogue, then it should be possible to isolate some evidence of longitudinal differentiation between Maori and Pakeha speakers (L07D)

Like should, must is also more commonly used to convey non-epistemic modality than epistemic modality. Collins (2009: 34) reports that $57.3 \%$ of must was used to convey deontic meaning, $32.8 \%$ epistemic meaning, $6.3 \%$ dynamic meaning and the remaining $3.6 \%$ indeterminate meaning. Similarly, Brewer (1987: 261) found that over $70 \%$ of must was used as an expression of deontic modality and the remaining as an expression of epistemic modality but with a deontic element in their meaning. In this study, non-epistemic must is much more common $(90.9 \%)$ than epistemic must (9.1\%). The rare occurences of epistemic must in academic writing have also been observed by Butler (1990) and Hyland (1998). This, Hyland (ibid.: 109) argues, "may suggest writers are reluctant to express even weak convictions concerning the truth of their propositions." As an expression of epistemic meaning, must is closely related to "confident inference" (Coates, 1983: 31). Must differs from should, according to Butler (1990: 162), in that it "expresses a higher degree of obligation, or a greater confidence in a conclusion from the evidence." The two examples below illustrate the use of epistemic must as a hedging device.

(25) In a sample of private debt Frankel and Litov do not find systematic evidence to support this hypothesis and conclude that any relation between covenants and conservatism must be marginal. (E09D)

(26) For the husk bridge to collapse, the 
narrower width of the bed $\underline{\text { must }}$ be sufficiently long to produce a bending stress that exceeds its allowable stress. (N08R)

\section{CONCLUSION}

The foregoing discussion has shown that there seems to be significant disciplinary variation in the use of modal auxiliaries as hedging devices in English research articles. As hedges, modal auxiliaries tend to be more common in soft sciences (linguistics and economics) than in hard sciences (engineering and natural sciences) whereas their use in health sciences (medicine) does not seem to show any significant difference as compared with soft and hard sciences. While the use of modal auxiliaries in medicine as well as in engineering supports Varttala's (2001) findings, the use of these modals in economics is much lower than that in Varttala. In addition, their use in natural sciences is also much lower than that in Hyland (1998). This disciplinary variation seems to have been caused mostly by different research traditions with linguistics and economics tending to be more discursive and interpretive, more tentative and more cautious in presenting knowledge claims than engineering, natural sciences and even medicine.

The study has also revealed that there seems to be significant disciplinary variation in the use of individual modals. While may is the one modal most commonly used in the five disciplines under investigation, would and will are the second most commonly used modals in linguistics, natural sciences and engineering. However, in economics would is third and will second. In medicine, the second and third most frequently used modals are might and would. This suggests a slightly different pattern of use of modal auxiliaries in each of the disciplines. In general, this study is consistent with Hyland (1998) and Varttala (2001), except for the use of will, which was found to be a common hedging device in this study, but rarely used in both Hyland and Varttala.

As the principal means of expressing hedging in English academic discourse, modal auxiliaries express tentativeness and possibility. They are therefore central to academic writing in which it is essential to present unproven propositions with caution and precision. They play a central role in the negotiation of claims for new knowledge and "in gaining ratification for claims for a powerful peer group by allowing writers to present statements with appropriate accuracy, caution, and humility, expressing possibility rather than certainty and prudence rather than overconfidence" (SalagerMeyer, 2011: 35-6). Yet, as they have many different and subtle meanings, modal auxiliaries are notoriously difficult for first or second language learners, let alone foreign language learners, to master (cf. Holmes, 1988: 21-2). Discussing the difficulties French and Dutch students face in learning to express appropriately modal meaning in English, Robberecht \& Peteghem (1982: 35-6, cited in Holmes, 1988: 22) observe that these students do not seem to have "feeling for" the nuances of modal verbs and do not use them as frequently as native speakers do. A similar observation was made by Kasper (1979: 276) about German learners of English, who generally show a "low awareness of modality as a pragmatic category" and also a low awareness of "the linguistic means whereby modality is realized." Furthermore, Ventola (1990) also observes that the mastery of modal auxiliaries expressing probability present Finnish writers with a challenge. She consequently concludes that such modal auxiliaries "should be one of the focal points of any course to improve the academic writing skills of nonnative speakers" (ibid.: 176). On the same note, considering all these difficulties that nonnative writers face in the use modal auxiliaries in English, it is suggested that in order for Indonesian scholars attempting to win the heart of international audience (Adnan \& Zifirdaus, 2005) through international publication in English, they have to equip themselves with ways of expressing degrees of possibility and tentativeness through the use of, among others, modal auxiliaries. This is important as such hedging devices can be used, as mentioned previously, to negotiate their knowledge claims and in turn to increase the opportunity for their claims to be ratified by their discourse community; thus increasing their visibility as credible scientists internationally.

\section{ACKNOWLEDGEMENTS}

This article is part of a project I am currently working on for my Ph.D. dissertation. Therefore, I would like to express my sincere gratitude to 
my advisors Prof. Stephanus Djawanai, Ph.D. and Prof. Dr. Soepomo Poedjosoedarmo for their invaluable comments, suggestions, assistance, and guidance for the completion of this article.

\section{REFERENCES}

Ädel, Annelie. (2006). Metadiscourse in L1 and L2 English. Amsterdam: John Benjamins.

Adnan, Zifirdaus \& I. Zifirdaus. (2005). Merebut Hati Audiens Internasional: Strategi Ampuh Meraih Publikasi di Jurnal Ilmiah. Jakarta: Gramedia.

Biber, Douglas \& James K. Jones. (2009). Quantitative methods in corpus linguistics. In Anke Lüdeling and Merja Kytö (eds.), Corpus Linguistics: An International Handbook. Berlin: Walter de Gruyter, 1286-304.

Boland, Annerieke. (2006). Aspect, Tense and Modality: Theory, Typology and Acquisition. Vols. 1 \& 2 . Utrecht, The Netherlands: LOT.

Bondi, M. (2006). A case in point: Signals of narrative development in Business and Economics. In K. Hyland \& M. Bondi (eds.), Academic Discourse across Disciplines. Bern: Peter Lang, 49-74.

Brewer, Nicola M. (1987). Modality and Factivity: One Perspective on the Meaning of the English Modal Auxiliaries. (Unpublished Dissertation). University of Leeds, Leeds, U.K.

Brown, Penelope \& Stephen Levinson. (1987). Politeness: Some Universals in Language Usage. Cambridge: Cambridge University Press.

Butler, Christopher S. (1990). Qualifications in science: Modal meanings in scientific texts. In Walter Nash (ed.), The Writing Scholar: Studies in Academic Discourse. Newbury Park, CA: Sage, 137-70.

Bybee, J. L. and S. Fleischman, S. (1995). Modality in grammar and discourse: an introductory essay. In J. L. Bybee and S. Fleischman (eds.), Modality in grammar and discourse. Amsterdam and Philadelphia: John Benjamins, $1-14$.

Carter, Ronald and Michael McCarthy. (2006). Cambridge Grammar of English: A Comprehensive Guide. Spoken and Written English Grammar and Usage. Cambridge: Cambridge University Press.

Coates, Jennifer. (1983). The Semantics of Modal Auxiliaries. London: Croom Helm.
Coates, Jennifer. (1987). Epistemic modality and spoken discourse. Transactions of the Philological Society 85: 100-31.

Coates, Jennifer. (1995). The expression of root and epistemic modality in English. In J.L. Bybee and S. Fleischman (eds.), Modality in Grammar and Discourse. Amsterdam: John Benjamins, 55-66.

Collins, Peter. (2009). Modals and Quasi-modals in English. Amsterdam: Rodopi.

Crismore, Avon \& Rodney Farnsworth. (1990). Metadiscourse in popular and professional science discourse. In William Nash (ed.), The Writing Scholar: Studies in Academic Discourse.NewburyPark,CA:Sage,118-136.

Crismore, Avon \& William J. Vande Kopple. (1988). Readers' learning from prose: The effects of hedges. Written Communication 5/2: 184-202.

Crompton, P. (1997). Hedging in academic writing: some theoretical problems. English for Specific Purposes 16/4, 271-287.

Depraetere, Ilse \& Susan Reed. (2006). Mood and modality in English. In Bas Aarts \& April McMahon (eds.), The Handbook of English Linguistics. Oxford: Blackwell, 269-290.

Fine, Kit. (2005). Modality and Tense: Philosophical Papers. Oxford: Oxford University Press.

Gomez, Pascual Cantos. (2002). Do we need statistics when we have linguistics? D.E.L.T.A. 18/2: 233-71.

Halliday, Michael A.K. (1970). Functional diversity in language as seen from a consideration of modality and mood in English. Foundations of Language 6: 322-361.

Halliday, Michael A.K. (2014). Halliday's Introduction to Functional Grammar (4 ${ }^{\text {th }}$ Ed.). Revised by Christian M.I.M. Matthiessen. London: Routledge.

Hermerén, L. (1978). On Modality in English: A Study of the Semantics of the Modals. Lund: CWK Gleerup.

Holmes, Janet. (1988). Doubt and certainty in ESL textbooks. Applied Linguistics 9: 21-44.

Huddleston, Rodney \& Geoffrey K. Pullum. (2002). The Cambridge Grammar of the English Language. Cambridge: Cambridge University Press.

Hyland, Ken. (1996a). Talking to the academy: Forms of hedging in science research articles. Written Communication 13/2: 251-81. 
Hyland, Ken. (1996b). Writing without conviction? Hedging in science research articles. Applied Linguistics 17/4: 433-454.

Hyland, Ken. (1998). Hedging in Scientific Research Articles. Amsterdam: John Benjamins.

Hyland, Ken. (1999). Disciplinary discourses: Writer stance in research articles. In C Candlin \& $\mathrm{K}$. Hyland (eds.), Writing: Texts, Processes and Practices. London: Longman, 99-121.

Hyland, Ken. (2008). Genre and academic writing in the disciplines. Language Teaching 41/4: 543-62.

Kasper, G. (1979). Communication strategies: Modality reduction. Interlanguage Studies Bulletin 4/2: 266-83.

Klinge, Alex. (1993). The English modal auxiliaries: from lexical semantics to utterance interpretation. Journal of Linguistics 29: 315 357.

Lakoff, George. (1973). Hedges: A study in meaning criteria and the logic of fuzzy concepts. Journal of Philosophical Logic 2: 458-508.

Leech, Geoffrey. (2004). Meaning and the English Verbs ( $3^{\text {rd }}$ ed.). London: Routledge.

Lyons, John. (1977). Semantics. Vols. 1 \& 2. Cambridge: Cambridge University Press.

Malavasi, D. \& D. Mazzi. (2008). 'It can be assumed that, if our conceptual model is valid, then ... ": The construction of multiple identities in Economics vs. Marketing. Linguistica $e$ Filologia 27: 157:79.

Markkanen, Raija \& Harmut Schr $\square$ der. (1989). Hedging as a translation problem in scientific texts. In Christer Lauren \& Marianne Nordman (ed.), Special Languages: From Human Thinking to Thinking Machines. London: Multilingual Matters, 171-75.

Markkanen, Raija \& Harmut Schr $\square$ der. (1992). Hedging and its linguistic realization in English, German and Finnish philosophical texts: A case study. In Marianne Nordman (ed.), Fachsprachliche Miniaturen. Frankfurt: Peter Lang, 121-30.

Markkanen, Raija \& Harmut Schr $\square$ der. (1997). Hedging: A challenge for pragmatics and discourse analysis. in Raija Markkanen \& Hartmut Schr $\square$ der (eds.): 3-18.

Markkanen, Raija \& Harmut Schr $\square$ der (eds.). (1997). Hedging and Discourse: Approaches to the Analysis of a Pragmatic Phenomenon in Academic Texts. Berlin: Walter de Gruyter.
Mauranen, Anna. (1997). Hedging in language revisers' hands. In Raija Markkanen \& Hartmut Schr $\square$ der (eds.): 115-33.

Minitab 17 Statistical Software. (2010). [Computer Software]. State College, PA: Minitab, Inc. (www.minitab.com)

Myers, Greg. (1989). The pragmatics of politeness in scientific articles. Applied Linguistics 10:1-35.

Palmer, Frank. (1990). Modality and the English Modals $\left(2^{\text {nd }}\right.$ ed.). London: Longman.

Palmer, Frank. (2001). Mood and Modality (2 ${ }^{\text {nd }}$ Ed.). Cambridge: Cambridge University Press.

Perkins, Michael. (1983). Modal Expressions in English. London: Frances Pinter.

Quirk, Randolph, Sidney Greenbaum, Geoffrey Leech \& Jan Svartvik. (1972). A Grammar of Contemporary English. London: Longman.

Quirk, Randolph, Sidney Greenbaum, Geoffrey Leech \& Jan Svartvik. (1985). A Comprehensive Grammar of the English Language. London: Longman.

Salager-Meyer, Françoise. (1994). Hedges and textual communicative function in medical English written discourse. English for Specific Purposes 13: 149-170.

Salager-Meyer, Françoise. (1997). I think that perhaps you should: A study of hedges in written academic discourse. In T. Miller (ed.), Functional Approaches to Written Discourse: Classroom Applications. Washington, D.C.: United States Information Agency.

Salager-Meyer, Françoise. (2011). Scientific discourse and contrastive linguistics: Hedging. European Science Editing 37/2: 35-37.

Sanjaya, I Nyoman Suka. (2013). Hedging and Boosting in English and Indonesian Research Articles. (Unpublished Dissertation). Pennsylvania State University, University Park, PA.

Scott, M. (2008). WordSmith Tools Version 5. Liverpool: Lexical Analysis Software.

Skelton, John. (1988a). The care and maintenance of hedges. ELT Journal 42/1: 37-43.

Skelton, John. (1988b). Comments in academic articles. In P. Grunwell (ed.), Applied Linguistics in Society. London: CILT/BAAL, 98-108.

Stubbs, Michael. (1986). 'A matter of prolonged field work': Notes towards a modal grammar of English. Applied Linguistics 7/1: 1-25. 
Swales, John. (1990). Genre Analysis: English in Academic and Research Settings. Cambridge: Cambridge University Press.

Taylor, G. \& T. Chen. (1991). Linguistic, cultural and subcultural issues in contrastive discourse analysis: Anglo-American and Chinese scientifictexts.AppliedLinguistics12:319-36.

Thomson Reuters. (2009). Arts and Humanities Citation Index. http://ipscience.thomson-reuters.com/ mjl/wos_ahci_a5020_final.pdf. Accessed 12/08/2009.

Thomson Reuters. (2009). Science Citation Index Expanded. http://ipscience.thomson-reuters. com/mjl/wos_scie_a5021_final.pdf. Accessed 12/08/2009.

Thomson Reuters. (2009). Social Science Citation Index. http://ipscience.thomson-reuters.com/ mjl/ wos_ssci_a5022_final.pdf. Accessed 12/08/2009.

Turnbull, William \& Karen L. Saxton. (1997). Modal expression as facework in refusals to comply with requests: I think I should say 'no' right now. Journal of Pragmatics 27/2: 145-181.

Van der Auwera, J. and V.A. Plungian. (1998). Modality's semantic map. Linguistic Typology 2, 79-124.

Varttala, Teppo. (2001). Hedging in Scientifically Oriented Discourse: Exploring Variation according to Discipline and Intended Audience. (Unpublished Dissertation). University of Tampere, Tampere, Finland.

Ventola, Aija. (1990). Modalization: Probability-An exploration into its role in academic writing. In Anna Duszak (ed.), Culture and Styles of Academic Discourse. Berlin: Mouton de Gruyter, 157-79. 